\title{
Obesity without comorbidity may also lead to non-thyroidal illness syndrome
}

\author{
Şakir Ö. Keşkek ${ }^{A, C-F}$, Özlem Kurşun ${ }^{A, B}$, Gülay Ortoğlu ${ }^{B, E}$, Mehmet Bankir ${ }^{A, E}$, \\ Zeynep Tüzün ${ }^{B}$, Tayyibe Saler ${ }^{D, F}$ \\ Department of Internal Medicine, Numune Training and Research Hospital, Adana, Turkey \\ A - research concept and design; $\mathrm{B}$ - collection and/or assembly of data; $\mathrm{C}$ - data analysis and interpretation; \\ $D$ - writing the article; $E$ - critical revision of the article; $F$ - final approval of the article
}

Address for correspondence

Şakir Keşkek

E-mail:drkeskek@yahoo.com

Funding sources

None declared

Conflict of interest

None declared

Received on 0ctober 27,2016

Reviewed on December 1, 2016

Accepted on April 5, 2017

\section{Abstract}

Background. Obesity mediates a series of operations in the body by increasing the production of proinflammatory cytokines. Cytokines play an important role in the development of non-thyroidal illness syndrome (NTIS).

Objectives. The aim of this study was to investigate the association between obesity and NTIS.

Material and methods. A total of 423 subjects were included. The study group was comprised of 219 obese patients without any comorbid disease and the control group was comprised of 204 healthy subjects. Body mass index (BMI), thyroid hormone levels, high-sensitivity C-reactive protein (hs-CRP) levels, erythrocyte sedimentation rate (ESR), complete blood count, and other biochemical parameters were measured. Frequencies of NTIS were calculated. MedCalc v. 12.5 software program (MedCalc, Ostend, Belgium) was used for statistical analysis.

Results. Groups were statistically different according to BMI $(p<0.001)$. The mean BMls of the study and the control group were $34.6 \pm 5.0 \mathrm{~kg} / \mathrm{m}^{2}$ and $22.6 \pm 1.8 \mathrm{~kg} / \mathrm{m}^{2}$, respectively. Obese patients had higher serum hs-CRP levels, ESR and white blood cells (WBC) levels $(0.99 \pm 3.17 \mathrm{mg} / \mathrm{L}$ vs $0.39 \pm 1.09 \mathrm{mg} / \mathrm{L} ; 17.2 \pm 10.6 \mathrm{~mm} / \mathrm{h}$ vs $12.6 \pm 8.0 \mathrm{~mm} / \mathrm{h} ; .8 \pm 2.110^{3} / \mu \mathrm{L}$ vs $6.9 \pm 1.510^{3} / \mathrm{LL}$, respectively; $\mathrm{p}<0.001$ ). There were 21 (9.5\%) obese patients with NTIS, while there were none NTIS cases in the control group. The difference was statistically significant $(p<0.001)$. There was a strong association between obesity and NTIS (odds ratio $(O R)=44.2$, $95 \%$ confidence interval $(C \mathrm{C})=2.66-736.3 ; \mathrm{p}=0.0082)$.

Conclusions. Inflammation, which is strongly associated with adipose tissue, may lead to NTIS in obese patients without any comorbid disease.

Key words: obesity, high-sensitivity C-reactive protein, erythrocyte sedimentation rate, white blood cell, non-thyroidal illness syndrome

DOI

10.17219/acem/70226

Copyright

Copyright by Author(s)

This is an article distributed under the terms of the

Creative Commons Attribution Non-Commercial License

(http://creativecommons.org/licenses/by-nc-nd/4.0/) 


\section{Introduction}

Obesity has a high prevalence throughout the world. The World Health Organization (WHO) reported that more than 1.9 billion adults were overweight in 2014 . Obesity has become an important public health problem because of its related complications. It can lead to diabetes mellitus, hypertension, cardiovascular disease, and other chronic disorders. ${ }^{1-3}$ Multiple etiological factors have been connected to the genesis of obesity, of which genetic susceptibility, high calorie intake, lifestyle, and psychiatric illness are important. ${ }^{1-4}$

The production of cytokines, chemokines and coagulation proteins increase in the case of obesity due to the increased adipose tissue, which is an endocrine organ. This condition brings about several reactions in the body. These pathophysiological reactions can stimulate endoplasmic reticulum stress and inflammation in various cells. Inflammation and lipotoxicity play an important role in the progression of chronic diseases associated with obesity. ${ }^{7}$

Abnormalities in thyroid hormone levels in the absence of underlying thyroid disease can be found in the case of acute or severe disease. Illness results in profound changes in thyroid hormone metabolism called the sick euthyroid syndrome or non-thyroidal illness syndrome (NTIS). Although the etiologic mechanism of NTIS is not well-known, there are several theories regarding the disease. The $1^{\text {st }}$ theory concerns the difference between the effects of type I and type II deiodinase, which are mediated by inflammatory cytokines; the $2^{\text {nd }}$ theory focuses on decreased hypothalamus and pituitary response to thyroid hormones; the $3^{\text {rd }}$ theory concerns lower levels of T4 binding protein and cellular uptake. ${ }^{8}$

According to the previous studies, obesity is an inflammatory disease and inflammation has negative effects on thyroid metabolism. ${ }^{5-7}$ The aim of the current study was to investigate the association between obesity and NTIS in obese patients without any comorbid disease.

\section{Material and methods}

This cross-sectional cohort study was carried out in $\mathrm{Nu}$ mune Training and Research Hospital, Adana, Turkey, from December 2013 to May 2015. Approval for the study protocol was granted by the hospital institutional review board (approval No: ANEAH.EK 2013/60) and the study was conducted in accordance with the Declaration of Helsinki, as revised in 2008. Informed consent was obtained from all participants before enrollment. All applications were concordant with the Good Clinical Practice standards.

A total of 423 subjects of both genders were enrolled. The study group comprised 219 obese patients without any comorbid disease and the control group comprised 204 healthy subjects. Patients with a diagnosis of any acute or chronic disease, and patients with a history of thyroid diseases (primary, secondary or autoimmune) were excluded. Pregnant or breastfeeding women were also excluded.

Biochemical tests were performed, and body mass index (BMI) and blood pressure were measured. Blood pressure of patients was measured after $10 \mathrm{~min}$ of rest with calibrated sphygmomanometers (Erka, Bad Tölz, Germany) at least 2 times. Body mass index was calculated by weight $[\mathrm{kg}] /$ height $\left[\mathrm{m}^{2}\right]$.

A venous blood sample for biochemical tests was collected in the morning following overnight fasting. Fasting glucose, serum lipids, creatinine, aspartate aminotransferase (AST), alanine aminotransferase (ALT), insulin, insulin resistance, thyrotropin (thyroid stimulating hormone - TSH), free triiodothyronine (FT3), free thyroxine (FT4), erythrocyte sedimentation rate (ESR), and high-sensitivity $\mathrm{C}$-reactive protein (hs-CRP) levels were measured. A complete blood count was performed. The levels of TSH, FT3, FT4, and insulin were measured by the Abbott Architect i2000 SR analyzer system (Abbott Laboratories, Abbot Park, USA). Fasting glucose, triglyceride, low-density lipoprotein (LDL) and high-density lipoprotein (HDL) levels were analyzed with an automatic analyzer (Roche C-501; Roche, Tokyo, Japan) by using the hexokinase method (glucose) and the homogeneous colorimetric enzyme test (triglyceride, LDL and HDL). Other biochemical values (creatinine, AST and ALT) were analyzed with Beckman Coulter Synchron LX 20 (Beckman Coulter, Brea, USA), using commercially available kits (original Beckman Coulter reagents). Complete blood counts were measured with Sysmex XE 2100i (Sysmex, Kobe, Japan) by fluorescence flow cytometry. Erythrocyte sedimentation rates were measured using the Westergren method with Sed Rate Screener 100 (Greiner Bio-One GmbH, Kremsmünster, Austria). The level of hs-CRP was analyzed using the immunoturbidimetric method with Roche Integra 400 (Roche). Insulin resistance (homeostasis model assessment of insulin resistance - HOMA-IR) was calculated according to the fasting insulin $\times$ fasting glucose $/ 405$ formulas.

Patients with a BMI higher than $30 \mathrm{~kg} / \mathrm{m}^{2}$ were defined as obese. Non-thyroidal illness syndrome was diagnosed when free FT3 levels were below the normal range, and/or FT4 levels were within the normal or low values, and TSH levels were within the normal or low values. ${ }^{9}$

Statistical analyses were performed using the MedCalc v. 12.5 software program (MedCalc, Ostend, Belgium). Categorical measurements were reported as number and percentage. Quantitative measurements were reported as mean \pm standard deviation (SD). The Kolmogorov-Smirnov test was used to show normal distribution of quantitative measurements. The $X^{2}$ test was used to compare categorical (gender) measures and frequency of thyroid dysfunction between the groups. The t-test or the Mann-Whitney U test were used for comparison of biochemical tests and thyroid hormone concentrations between the 2 groups. Pearson's correlation coefficient was used 
to analyze the degree of association between 2 variables. A log transformation was used for the variables that were not normally distributed. The odds ratio (OR) was used to analyze the degree of association between NTIS and obesity. An overall p-value $<0.05$ was considered a statistically significant result.

\section{Results}

The mean age of the study group (obese patients) and control group (healthy patients) was $38.6 \pm 10.9$ years and $37.2 \pm 12.1$ years, respectively. There were $163(74.4 \%)$ women and $56(25.6 \%)$ men in the study group, and 139 (68.1\%) women and 65 (31.9\%) men in the control group. There was no statistically significant difference in the age and gender distribution in the 2 groups ( $\mathrm{p}=0.065$ and $\mathrm{p}=0.153$, respectively) (Table 1 ). The mean BMI of the obese patients was $34.6 \pm 5.0 \mathrm{~kg} / \mathrm{m}^{2}$, while it was $22.6 \pm 1.8 \mathrm{~kg} / \mathrm{m}^{2}$ in healthy subjects. The groups were statistically different regarding BMI $(\mathrm{p}<0.001)$ (Table 1$)$.

The groups were comparable in terms of blood glucose, triglyceride, HDL, LDL, AST, ALT, and creatinine levels,

Table 1. Demographic and clinical properties of the groups

\begin{tabular}{|c|c|c|c|}
\hline Variables & $\begin{array}{l}\text { Obese group } \\
\qquad(n=219)\end{array}$ & $\begin{array}{l}\text { Healthy group } \\
\qquad(n=204)\end{array}$ & $\mathrm{p}$-value \\
\hline Age [years] & $38.6 \pm 10.9$ & $37.2 \pm 12.1$ & 0.065 \\
\hline Female & $163(74.4)$ & $139(68.1)$ & 0.153 \\
\hline BMI $\left[\mathrm{kg} / \mathrm{m}^{2}\right]$ & $34.6 \pm 5.0$ & $22.6 \pm 1.8$ & $<0.001$ \\
\hline Glucose [mg/dL] & $91.6 \pm 6.5$ & $90.7 \pm 6.4$ & 0.145 \\
\hline Insulin $[\mu \mathrm{U} / \mathrm{mL}]$ & $16.3 \pm 14.4$ & $10.9 \pm 7.5$ & $<0.001$ \\
\hline HOMA-IR & $3.4 \pm 2.0$ & $2.4 \pm 1.7$ & $<0.001$ \\
\hline Triglyceride [mg/dL] & $133.1 \pm 47.5$ & $126.9 \pm 57.8$ & 0.082 \\
\hline $\mathrm{HDL}[\mathrm{mg} / \mathrm{dL}]$ & $44.9 \pm 14.6$ & $47.3 \pm 12.1$ & 0.064 \\
\hline $\mathrm{LDL}[\mathrm{mg} / \mathrm{dL}]$ & $124.5 \pm 34.0$ & $117.3 \pm 26.0$ & 0.144 \\
\hline $\mathrm{SBP}[\mathrm{mm} \mathrm{Hg}]$ & $118.0 \pm 10.1$ & $117.6 \pm 7.4$ & 0.654 \\
\hline $\mathrm{DBP}[\mathrm{mm} \mathrm{Hg}]$ & $72.3 \pm 5.7$ & $71.9 \pm 5.1$ & 0.520 \\
\hline $\mathrm{ALT}[\mathrm{IU} / \mathrm{L}]$ & $19.2 \pm 9.6$ & $18.5 \pm 8.9$ & 0.095 \\
\hline AST [IU/L] & $20.2 \pm 11.3$ & $18.6 \pm 10.6$ & 0.115 \\
\hline Creatinine $[\mathrm{mg} / \mathrm{dL}]$ & $0.76 \pm 0.22$ & $0.74 \pm 0.24$ & 0.660 \\
\hline
\end{tabular}

Data is presented as mean \pm standard deviation (SD) or as $n(\%)$. $\mathrm{BMI}$ - body mass index; HOMA-IR - homeostasis model assessment of insulin resistance; LDL - low-density lipoprotein, $\mathrm{HDL}$ - highdensity lipoprotein, AST - aspartate aminotransferase, ALT -alanine aminotransferase; SBP - systolic blood pressure; DBP - diastolic blood pressure.

Table 2. WBC, ESR and hs-CRP levels of the groups

\begin{tabular}{|l|c|c|c|}
\multicolumn{1}{|c|}{ Variables } & $\begin{array}{c}\text { Obese group } \\
(n=219)\end{array}$ & $\begin{array}{c}\text { Healthy group } \\
(n=204)\end{array}$ & $p$-value \\
\hline WBC $\left[10^{3} / \mu \mathrm{L}\right]$ & $7.8 \pm 2.1$ & $6.9 \pm 1.5$ & $<0.001$ \\
\hline ESR $[\mathrm{mm} / \mathrm{h}]$ & $17.2 \pm 10.6$ & $12.6 \pm 8.0$ & $<0.001$ \\
\hline hs-CRP $[\mathrm{mg} / \mathrm{L}]$ & $0.99 \pm 3.17$ & $0.39 \pm 1.09$ & $<0.001$ \\
\hline
\end{tabular}

Data is presented as mean \pm standard deviation (SD). WBC - white blood cells; ESR - erythrocyte sedimentation rate; hs-CRP - high-sensitivity C-reactive protein. as well as systolic blood pressure (SBP) and diastolic blood pressure (DBP) ( $p>0.05$, for each) (Table 1). The mean serum insulin level $(16.3 \pm 14.4 \mu \mathrm{U} / \mathrm{mL}$ vs $10.9 \pm 7.5 \mu \mathrm{U} / \mathrm{mL}$; $\mathrm{p}<0.001)$ and HOMA-IR $(3.4 \pm 2.0$ vs $2.4 \pm 1.7$; $\mathrm{p}<0.001)$ were high in obese patients (Table 1 ).

The mean serum hs-CRP levels of the study and control groups were $0.99 \pm 3.17 \mathrm{mg} / \mathrm{L}$ and $0.39 \pm 1.09 \mathrm{mg} / \mathrm{L}$, respectively. There was a statistically significant difference between the groups regarding the hs-CRP level ( $\mathrm{p}<0.001$ ) (Table 2). The levels of ESR and white blood cells (WBC) were higher in obese patients. The mean ESR level was $17.2 \pm 10.6 \mathrm{~mm} / \mathrm{h}$ in obese patients, while it was $12.6 \pm 8.0 \mathrm{~mm} / \mathrm{h}$ in healthy subjects $(\mathrm{p}<0.001)$. The mean level of WBC was $7.8 \pm 2.110^{3} / \mu \mathrm{L}$ in obese patients, while it was $6.9 \pm 1.510^{3} / \mu \mathrm{L}$ in healthy subjects $(\mathrm{p}<0.001)$ (Table 2$)$.

The groups were comparable regarding the thyroid hormone levels (TSH, FT3 and FT4) ( $\mathrm{p}>0.05$, for each). There were $21(9.5 \%)$ obese patients with NTIS, while there were none NTIS cases in the control group. The difference was statistically significant $(\mathrm{p}<0.001)$ (Table 3$)$.

Obese patients with NTIS $(\mathrm{n}=21)$ had higher hs-CRP levels and ESR compared to obese patients without NTIS $(\mathrm{n}=198)$. The level of hs-CRP and ESR in obese subjects with NTIS were $2.58 \pm 8.3 \mathrm{mg} / \mathrm{L}$ and $23.3 \pm 16.2 \mathrm{~mm} / \mathrm{h}$, respectively, while they were $0.81 \pm 1.9 \mathrm{mg} / \mathrm{L}$ and $16.6 \pm 9.7 \mathrm{~mm} / \mathrm{h}$, respectively, in obese subjects without NTIS ( $\mathrm{p}=0.015$ and $\mathrm{p}=0.005$, respectively) (Table 4 ).

Table 3. Thyroid hormone levels and frequency of NTIS of the groups

\begin{tabular}{|l|c|c|c|}
\multicolumn{1}{|c|}{ Variables } & $\begin{array}{c}\text { Obese group } \\
(\mathrm{n}=219)\end{array}$ & $\begin{array}{c}\text { Healthy group } \\
(\mathrm{n}=204)\end{array}$ & p-value \\
\hline FT3 $[\mathrm{pg} / \mathrm{mL}]$ & $3.1 \pm 0.58$ & $3.2 \pm 0.35$ & 0.090 \\
\hline FT4 $[\mathrm{ng} / \mathrm{dL}]$ & $1.17 \pm 0.3$ & $1.11 \pm 0.21$ & 0.095 \\
\hline TSH $[\mathrm{mclU} / \mathrm{mL}]$ & $1.96 \pm 1.0$ & $1.78 \pm 0.88$ & 0.127 \\
\hline $\begin{array}{l}\text { Frequency } \\
\text { of NTIS }\end{array}$ & $21(9.5)$ & $0(0)$ & $<0.001$ \\
\hline
\end{tabular}

Data is presented as mean \pm standard deviation (SD) or as $n(\%)$. NTIS - non-thyroidal illness syndrome; FT3 - free triiodothyronine; FT4 - free thyroxine; TSH - thyroid-stimulating hormone.

Table 4. Comparison of obese patients according to NTIS

\begin{tabular}{|l|c|c|c|}
\multicolumn{1}{|c|}{ Variables } & $\begin{array}{c}\text { Obese patients } \\
\text { NTIS (+) }\end{array}$ & $\begin{array}{c}\text { Obese patients } \\
\text { NTIS (-) }\end{array}$ & p-value \\
\hline WBC $\left[10^{3} / \mu \mathrm{L}\right]$ & $7.7 \pm 2.2$ & $7.8 \pm 2.0$ & 0.483 \\
\hline ESR $[\mathrm{mm} / \mathrm{h}]$ & $23.3 \pm 16.2$ & $16.6 \pm 9.7$ & 0.005 \\
\hline hs-CRP $[\mathrm{mg} / \mathrm{L}]$ & $2.58 \pm 8.3$ & $0.81 \pm 1.9$ & 0.015 \\
\hline
\end{tabular}

Data is presented as mean \pm standard deviation (SD). NTIS - nonthyroidal illness syndrome; WBC - white blood cells; ESR - erythrocyte sedimentation rate; hs-CRP - high-sensitivity C-reactive protein.

Table 5. Correlations of hs-CRP with BMI, FT3 and HOMA-IR

\begin{tabular}{|l|c|c|c|}
\multicolumn{1}{|c|}{ Variables } & BMI & FT3 & HOMA-IR \\
\hline hs-CRP & $r=0.416$ & $r=-0.176$ & $r=0.170$ \\
& $p<0.01$ & $p=0.009$ & $p=0.011$ \\
\hline
\end{tabular}

hs-CRP - high-sensitivity C-reactive protein; BMI - body mass index; FT3 - free triiodothyronine; HOMA-IR - homeostasis model assessment of insulin resistance. 

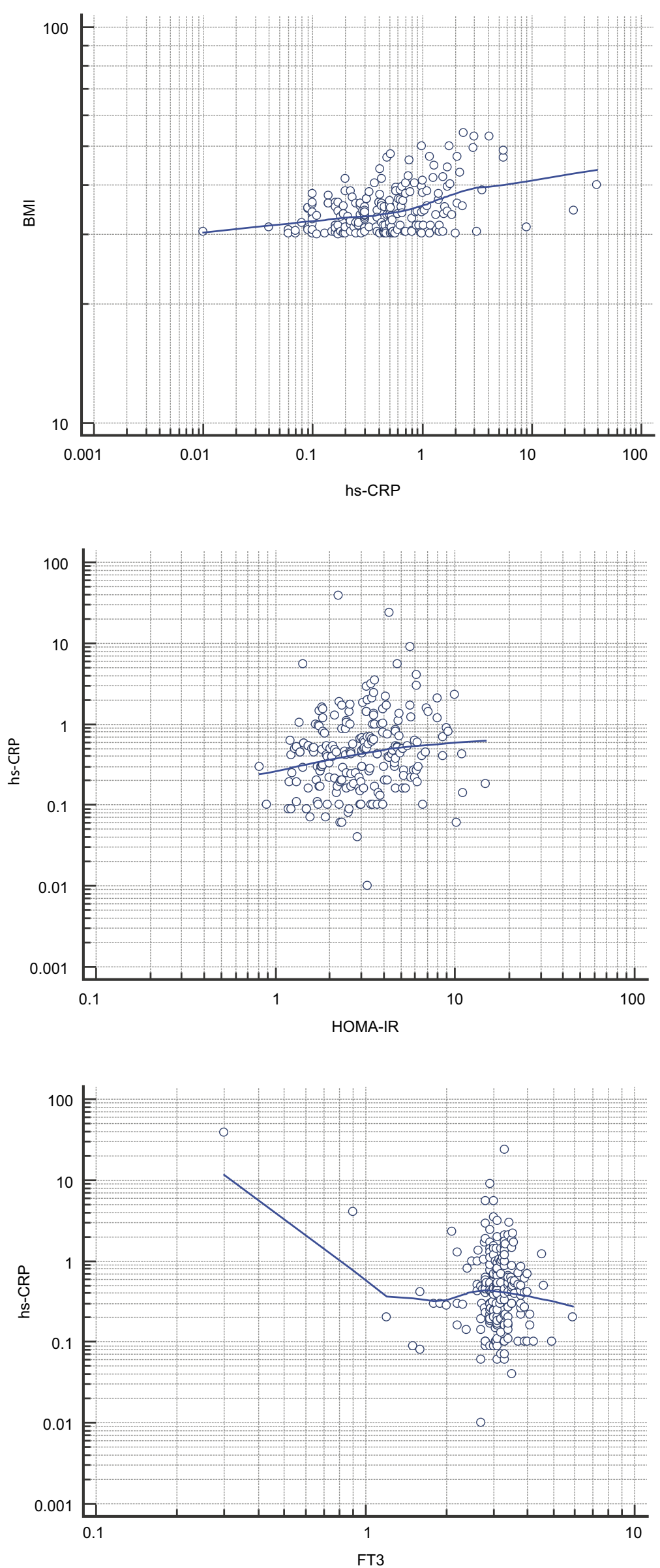

Fig. 1. Correlation between hs-CRP and BMI

In a scatter diagram, the correlation between hs-CRP and BMI has been shown graphically. The horizontal axis defines hsCRP and the vertical axis defines BMI.

$\mathrm{BMI}$ - body mass index; hs-CRP - high-sensitivity C-reactive protein.

Fig. 2. Correlation between hs-CRP and HOMA-IR

In a scatter diagram, the correlation between hs-CRP and HOMA-IR has been shown graphically. The vertical axis defines hs-CRP and the horizontal axis defines HOMA-IR.

hs-CRP - high-sensitivity C-reactive protein; HOMA-IR - homeostasis model assessment of insulin resistance.

Fig. 3. Correlation between hs-CRP and FT3

In a scatter diagram, the correlation between hs-CRP and FT3 has been shown graphically. The vertical axis defines hs-CRP and the horizontal axis defines FT3.

hs-CRP - high-sensitivity C-reactive protein; FT3 - free triiodothyronine. 
A positive correlation was found between hs-CRP level and BMI ( $\mathrm{r}=0.416$; $\mathrm{p}<0.01$ ) (Table 5, Fig. 1), and between hs-CRP level and HOMA-IR ( $r=0.170 ; \mathrm{p}=0.011)$ (Table 5, Fig. 2) in the study group, according to Pearson's correlation analyses. Additionally, a negative correlation was found between hs-CRP and FT3 levels ( $r=-0.176$; $\mathrm{p}=0.009$ ) (Table 5, Fig. 3). There was a strong association between obesity and NTIS (OR $=44.2$; confidence interval $(C I)=95 \% 2.66-736.3 ; \mathrm{p}=0.0082)$.

\section{Discussion}

A high frequency of NTIS in obese patients was found in this study. Moreover, a potent association between NTIS and obesity was also shown. Non-thyroidal illness syndrome is an abnormality of thyroid hormone concentration observed in a wide variety of acute or severe diseases without underlying thyroid illness. Inhibition of hepatic enzyme and deiodinases mediated by inflammatory cytokines strongly contributes to the development of NTIS. ${ }^{10,11}$

Obesity degenerates tissue functions and increases the development of a number of diseases, such as high blood pressure, atherosclerosis, diabetes, and non-alcoholic fatty liver disease. ${ }^{1,2,12}$ On the other hand, obesity is also an inflammatory disease. Expression and secretion of proinflammatory cytokines, such as tumor necrosis factor alpha (TNF- $\alpha$ ), monocyte chemoattractant protein 1 (MCP1), interleukin 6 (IL-6), CRP, and plasminogen activator inhibitor type 1 (PAI-1) are increased by the adipose tissue of obese individuals. ${ }^{13-15}$ As evidence of inflammation, we found high levels of hs-CRP, ESR and WBC in obese individuals. We also showed a significant correlation between hs-CRP and BMI. In accordance with this link, Ramírez Alvarado and Sánchez Roitz reported that serum levels of CRP, and therefore subclinical inflammation, seemed to be associated with high rates of anthropometric measures in the South American population. ${ }^{16}$

Genes involved in the production and release of $\mathrm{T} 4$ and T3 are severely affected by high concentrations of pro-inflammatory cytokines. ${ }^{17}$ Therefore, cytokines play an important role in the development of NTIS. Interleukin 6 was found to be negatively correlated with serum T3 concentrations in hospitalized patients. ${ }^{18}$ Davies et al. reported an association between elevated serum IL- 6 concentrations and changes in circulating thyroid hormones in NTIS, secondary to several medical conditions. ${ }^{19}$ Tumor necrosis factor alpha was found to be a mediator of several disorders leading to hypothalamic-pituitary dysfunction. Research of the effects of administering TNF- $\alpha$ and IL- $1 \beta$ to animals and humans showed their possible role in the pathogenesis of NTIS, with each cytokine stimulating critical illness and changes of low serum T3. ${ }^{20-23}$ Further reinforcing this link, Tognini et al. reported an inverse correlation between FT3 and hs-CRP levels in 301 critically ill patients. ${ }^{24}$ In the current study, we found higher levels of hs-CRP in obese patients with NTIS. Additionally, we showed an inverse correlation between hs-CRP and serum FT3.

Chronic inflammation plays a significant role in the pathophysiologic mechanism of insulin resistance. Increased secretion of TNF- $\alpha$ from the adipose tissue of obese individuals has been reported previously. ${ }^{5,25,26}$ Additionally, insulin resistance was found to be associated with TNF- $\alpha$ levels. ${ }^{5,25}$ Tumor necrosis factor alpha promotes inflammation and suppresses insulin sensitivity in insulin target cells. Elevated plasma TNF- $\alpha$ level may be an important mediator of insulin resistance by impairing insulin signaling. ${ }^{5,25,26}$ Furthermore, CRP, which is an acute phase reactant and an inflammatory signal, is commonly elevated in the case of insulin resistant disorders. ${ }^{27}$ In this study, high serum insulin levels and HOMAIR index were shown in obese subjects. Moreover, a significant positive correlation was shown between hs-CRP level and HOMA-IR. Low levels of anti-inflammatory and antidiabetic adiponectins have also been shown in obese subjects previously. ${ }^{28}$ In accordance with this link, Menon et al. examined the effects of surgically removing visceral adipose tissue in Ames dwarf mice. They concluded that the altered profile of adipokines secreted by visceral fat might play a key role in increased insulin sensitivity. ${ }^{29}$ Similarly, Masternak et al. investigated the effects of visceral fat removal in normal and growth hormone receptorresistant mice. They reported that visceral fat removal had a beneficial effect on insulin sensitivity in normal mice. ${ }^{30}$ The results of the current study are supported by studies carried out by both Menon et al. and Masternak et al. ${ }^{29,30}$

Our study had also some limitations. Firstly, it could have been beneficial if reverse triiodothyronine (rT3) had been measured in obese patients with NTIS. Secondly, well-balanced diets and regular exercise are important components of the overall approach to treating obesity. We suggested well-balanced diets and regular exercise for all patients. However, we did not check the patients after weight loss for NTIS.

On the other hand, we have some powerful points. Firstly, according to the power analyses (80\%), the sample size of the current study was sufficient for clear results. Secondly, the extensive exclusion criteria is another strong point. The obese individuals in this study had no disease other than obesity. According to our best knowledge, this is the first study that investigates NTIS in obese patients without any comorbid disease.

\section{Conclusions}

In conclusion, NTIS can be found in obese patients without any comorbid disease. Obesity can degenerate tissue functions due to the increased expression and secretion of proinflammatory cytokines. Abnormalities in thyroid hormone levels in the absence of underlying thyroid disease can be found in the case of severe diseases. 
Inflammation, which is strongly associated with obesity, can lead to NTIS in these patients. Finally, obese patients without any comorbidity should be evaluated for NTIS before treating thyroid dysfunctions.

\section{References}

1. World Health Organization. Obesity and overweight. http://www. who.int/mediacentre/factsheets/fs311/en//. Accessed December 2, 2017.

2. Visscher TL, Seidell JC. The public health impact of obesity. Annu Rev Public Health. 2001;22:355-375.

3. Rippey FF. Thrombosis and embolism. In: General Pathology. Johannesburg, South Africa: Witwatersrand University Press; 2003:103-109.

4. Rang HP, Dale MM, Ritter JM, Moore PK. Pharmacology. New Delhi, India: Churchill Livingstone; 2006:394-403.

5. Hotamisligil GS, Arner P, Caro JF, Atkinson RL, Spiegelman BM. Increased adipose tissue expression of tumor necrosis factor-alpha in human obesity and insulin resistance. J Clin Invest. 1995;95(5): 2409-2415. doi: 10.1172/JCI117936

6. Mathieu P, Poirier P, Pibarot P, Lemieux I, Després JP. Visceral obesity: The link among inflammation, hypertension, and cardiovascular disease. Hypertension. 2009;53(4):577-584.

7. Hotamisligil GS. Role of endoplasmic reticulum stress and c-Jun NH2terminal kinase pathways in inflammation and origin of obesity and diabetes. Diabetes. 2005;54(Suppl 2):S73-S78.

8. De Groot LJ. Non-thyroidal illness syndrome is a manifestation of hypothalamic-pituitary dysfunction, and in view of current evidence, should be treated with appropriate replacement therapies. Crit Care Clin. 2006;22(1):57-86.

9. Adler SM, Wartofsky L. The nonthyroidal illness syndrome. Endocrinol Metab Clin North Am. 2007;36(3):657-672.

10. Demers LM, Spencer $C$. The thyroid. Pathophysiology and thyroid testing. In: Burtis CA, Ashwood ER, Bruns DE, eds. Tietz Textbook of Clinical Chemistry and Molecular Diagnostics. $4^{\text {th }}$ ed. St. Louis, MO: Elsevier; 2006.

11. Mclver B, Gorman CA. Euthyroid sick syndrome: An overview. Thyroid. 1997;7(1):125-132.

12. Flegal KM, Graubard BI, Williamson DF, Gail M. Cause-specific excess deaths associated with underweight, overweight, and obesity. JAMA. 2007;298(17):2028-2037.

13. Mohamed-Ali V, Goodrick S, Rawesh A, et al. Subcutaneous adipose tissue releases interleukin-6, but not tumor necrosis factor-alpha, in vivo. J Clin Endocrinol Metab. 1997;82(12):4196-4200.

14. Fried SK, Bunkin DA, Greenberg AS. Omental and subcutaneous adipose tissues of obese subjects release interleukin-6: Depot difference and regulation by glucocorticoid. J Clin Endocrinol Metab. 1998;83(3):847-850.
15. Visser M, Bouter LM, McQuillan GM, Wener MH, Harris T. Elevated C-reactive protein levels in overweight and obese adults. JAMA. 1999; 282(22):2131-2135.

16. Ramírez Alvarado MM, Sánchez Roitz C. Relation of serum levels of C-reactive protein to anthropometric measurements: A systematic review of studies in South America [in Spanish]. Nutr Hosp. 2012;27(4):971-977.

17. Bartalena L, Brogioni S, Grasso L, Velluzzi F, Martino E. Relationship of the increased serum interleukin- 6 concentration to changes of thyroid function in nonthyroidal illness. J Endocrinol Invest. 1994; 17(4):269-274.

18. Boelen A, Platvoet-Ter Schiphorst MC, Wiersinga WM. Association between serum interleukin- 6 and serum 3,5,3'-triiodothyronine in nonthyroidal illness. J Clin Endocrinol Metab. 1993;77(6):1695-1699.

19. Davies PH, Black EG, Sheppard MC, Franklyn JA. Relation between serum interleukin- 6 and thyroid hormone concentrations in 270 hospital in-patients with non-thyroidal illness. Clin Endocrinol. 1996;44 (2):199-205.

20. Rasmussen AK. Cytokine actions on the thyroid gland. Dan Med Bull. 2000;47(2):94-114.

21. Ozawa M, Sato K, Han DC, Kawakami M, Tsushima T, Shizume K. Effects of tumor necrosis factor-alpha on thyroid hormone metabolism in mice. Endocrinology. 1988;123(3):1461-1467.

22. van der Poll T, Romijn JA, Wiersinga WM, Sauerwein HP. Tumor necrosis factor: A putative mediator of the sick euthyroid syndrome. J Clin Endocrinol Metab. 1991;71(6):1567-1572.

23. Hermus AR, Sweep CG. Cytokines and the hypothalamic-pituitaryadrenal axis. J Steroid Biochem Mol Biol. 1990;37(6):867-871.

24. Tognini S, Marchini F, Dardano A, et al. Non-thyroidal illness syndrome and short-term survival in a hospitalised older population. Age Ageing. 2010;39(1):46-50.

25. Hotamisligil GS, Shargill NS, Spiegelman BM. Adipose expression of tumor necrosis factor alpha: Direct role in obesity-linked insulin resistance. Science. 1993;259(5091):87-91.

26. Visser M, Bouter LM, McQuillan GM, Wener MH, Harris TB. Elevated C-reactive protein levels in overweight and obese adults. JAMA. 1999;282(22):2131-2135.

27. Sartipy $P$, Loskutoff DJ. Monocyte chemoattractant protein 1 in obesity and insulin resistance. Proc Natl Acad Sci U S A. 2003;100(12): 7265-7270.

28. El-Wakkad A, Hassan N-M, Sibaii H, El-Zayat SR. Proinflammatory, anti-inflammatory cytokines and adipokines in students with central obesity. Cytokine. 2013;61(2):682-687.

29. Menon V, Zhi X, Hossain T, et al. The contribution of visceral fat to improved insulin signaling in Ames dwarf mice. Aging Cell. 2014;13(3): 497-506.

30. Masternak MM, Bartke A, Wang F, et al. Metabolic effects of intraabdominal fat in GHRKO mice. Aging Cell. 2012;11(1):73-81. 